\title{
Evolution of sediment composition of the coastal Lake San Puoto (Latium, Italy) in the last two centuries
}

\author{
Francesca ALVISI* and Enrico DINELLI ${ }^{1)}$ \\ CNR - Istituto per la Geologia Marina, via Gobetti, 101; I-40129 Bologna, Italy \\ ${ }^{1)}$ Dipartimento di Scienze della Terra e Geologico-ambientali, Università di Bologna, Piazza di Porta San Donato, 1; I-40126 \\ Bologna, Italy \\ *e-mail corresponding author: e-mail: franci@igm.bo.cnr.it
}

\begin{abstract}
The sediment composition of the coastal Lake San Puoto (Central Italy) was studied to obtain information on its recent environmental evolution (last 200 years). The explorative fieldwork was performed within the framework of the EU-funded PALICLAS Project. Sediment and mass accumulation rates, calculated from ${ }^{210} \mathrm{~Pb}$ analysis, show mean values of $0.27 \mathrm{~cm} \mathrm{y}^{-1}$ and $0.11 \mathrm{~g} \mathrm{~cm}^{-2} y^{-1} \mathrm{re}$ spectively, with increasing values from $10 \mathrm{~cm}$ to the top (i.e. from ca $1960 \mathrm{AD}$ to the present). The evolution of the recent sedimentation of Lake San Puoto is characterized by the interplay of three main components: detrital (either siliciclastic and/or carbonatic), organic-rich and authigenic phases. The first reflects the input from coastal dunes and rocky outcrops; the other two indicate variations in lake productivity. Sedimentological, geochemical, and mineralogical analyses of two cores collected near the center of the lake were used to define five lithological units: i) a laminated unit representing the last eutrophication period, starting ca 1925 AD; ii) a few turbidite layers, probably due to a lowering of the lake level around 1920 AD; iii) a productive phase of the lake, which occurred around the end of the XIX and the beginning of the XX century; iv) a coarse siliciclastic sediment interval, possibly deposited following the digging of the channel connecting Lake San Puoto to Lake Lungo; and v) an older unit representing the natural allochthonous detritic sedimentation deriving from the present dune deposits surrounding the lake shores. Metal fluxes were calculated for recent times by means of ${ }^{210} \mathrm{~Pb}$ sedimentation rates. $\mathrm{Zn}, \mathrm{Cu}$ and $\mathrm{Pb}$ record considerably higher fluxes above $10 \mathrm{~cm}$ depth (i.e. 1960 AD), as confirmed by Al-normalized metal depth profiles. Episodes of eutrophication occurred between 1890 and 1920 and between 1925 and the present.
\end{abstract}

Key words: lacustrine sediment, geochemistry, ${ }^{210} \mathrm{~Pb}$ chronology, human impact, metal fluxes, Lake San Puoto, Latium, Italy

\section{INTRODUCTION}

Lacustrine sediments can be used in the study of the palaeoenvironmental evolution of a particular catchment basically because they reflect developments in the lake ecosystem and changes in the rate and type of processes such as weathering (e.g. Renberg et al. 1993; Duck et al. 1998; Rosen et al. 2000). Moreover, they are often deposited in undisturbed sedimentary environments and give time-integrated information on the evolution of the basin and its surroundings (e.g. Petterson et al. 1993). According to these characteristics, lacustrine sediments may record in detail the onset of anthropogenic influence, particularly regarding heavy metal pollution problems and eutrophication (Förstner \& Wittmann 1979; Håkanson \& Jansson 1983; Premazzi et al. 1986; Battarbee et al. 1990; Renberg et al. 1994; Das et al. 1995; Lottermoser et al. 1997; Baudo \& Beltrami 2001).

Within the framework of the EU funded PALICLAS Project, an explorative fieldwork was carried out in the coastal Lake San Puoto (Central Italy) to find a suitable lacustrine record, in particular with carbonate-rich sediments, to complete a possible transect between the Tyrrhenian and the Adriatic Sea. Correlation with other well-studied lacustrine records from lakes Monticchio and Albano in Central and Southern Italy (Robinson
1994; Calanchi et al. 1996; Lucchini et al. 1996) might be useful in defining the recent palaeoenvironmental evolution of the region, also because the lake is located almost half-way between the two well-investigated sites. Besides, the evaluation of sediment quality can enhance our understanding of the current environmental condition of the lake system, which is located near an important nature-reserve (Circeo National Park), and should reflect unpolluted or only mildly polluted conditions.

\section{GEOLOGIC AND GEOGRAPHIC SETTING}

Lake San Puoto (southern Latium) is a small basin located on the Fondi Plain close to a small limestone ridge, and is connected to the brackish coastal Lake Lungo by a canal (Fig. 1). It has a surface area of about $0.4 \mathrm{~km}^{2}$ and a volume of $10 \times 10^{6} \mathrm{~m}^{3}$, a mean depth of 25 $\mathrm{m}$ and a maximum depth of $37 \mathrm{~m}$. The lake surface is 2 $\mathrm{m}$ above the present sea level (Pagnotta et al. 1986) and about $1 \mathrm{~km}$ from the sea. There is little geological and morphological information available on the lake: it probably has steep slopes and a funnel-like shape similar to a maar lake or to a collapsed sinkhole, but its origin is still uncertain. The landscape around the basin is characterized by steep rocky slopes of Meso-Cenozoic limestone on the northeastern side, and on the other 
sides by a plain consisting of Pleistocene and Holocene aeolian, alluvial and colluvial deposits (Antonioli \& Frezzotti 1989).

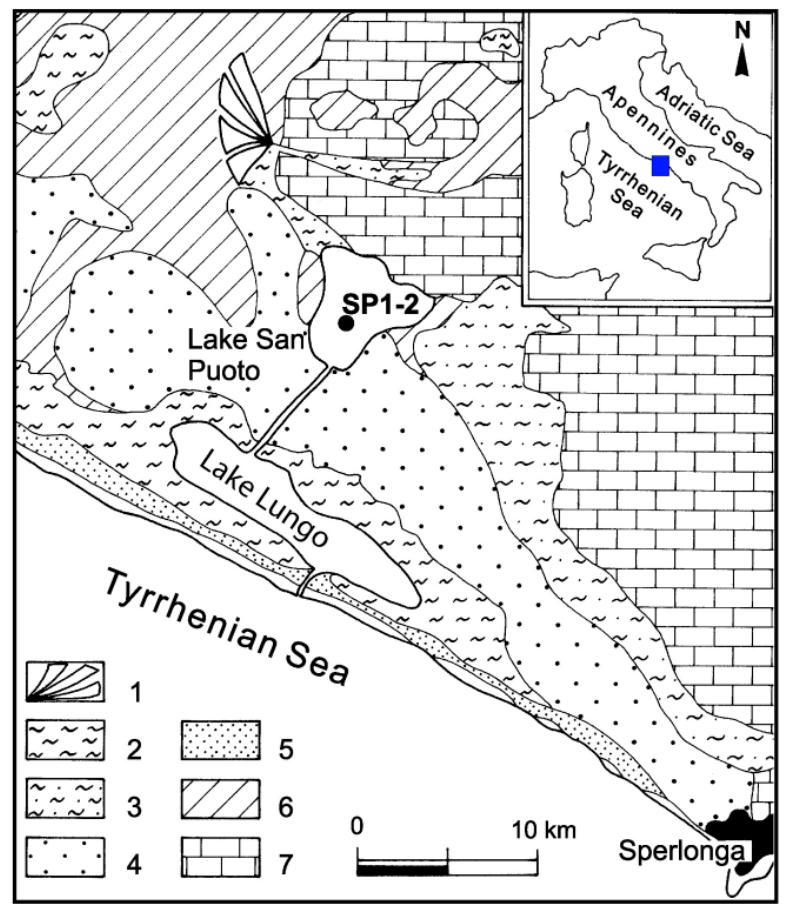

Fig. 1. Schematic geological map (simplified from: Antonioli et al. 1989) of the Lake San Puoto and sampling location. 1: alluvial fan (Upper Pleistocene-Holocene); 2: lacustrine, marsh and lagoon deposits (Holocene); 3: alluvial and colluvial deposits (Holocene); 4: eolic deposits (Holocene); 5 beach and eolic deposits (Holocene); 6: beach and eolic deposits (Upper Pleistocene); 7: limestone (Meso-Cenozoic).

\section{METHODS}

Two cores (SP1 and SP2) were collected in April 1995 near the center of the lake (32 $\mathrm{m}$ water depth) (Fig. 1), using a sediment-water interface corer (Busatti et al. 1980) with a Perspex tube $120 \mathrm{~cm}$ long and $60 \mathrm{~mm}$ in diameter. Both cores were scanned for whole-core volume magnetic susceptibility $(\mathrm{K})$ with a Bartington meter MS2 and a loop sensor ( $80 \mathrm{~mm}$ diameter) to allow lateral core and derived data correlations (Fig. 2) as suggested by Oldfield (1991) and Verosub \& Roberts (1995), and applied by many authors (e.g. Lami et al. 1994; Creer \& Morris 1996; Oldfield \& Frignani 1996; Rolph et al. 1996).

Core SP1 was cut lengthwise, photographed and Xradiographed for the lithological description (Tab. 1). Core SP2 was extruded and cut into $1 \mathrm{~cm}$ thick slices for the various analyses. Sedimentological, mineralogical, geochemical and radiometric analyses were carried out, about 20 samples being used for each method.

The samples were dried at $60{ }^{\circ} \mathrm{C}$ and the water content was used to calculate porosity and bulk dry density, assuming a constant sediment density of $2.5 \mathrm{~g} \mathrm{~cm}^{-3}$. The dry sediment was then slightly disaggregated and ana- lyzed for radiotracers. ${ }^{210} \mathrm{~Pb}$ specific activities were measured by alpha-counting ${ }^{210} \mathrm{Po}$ after acid leaching and spontaneous deposition on silver disks. Samples were analyzed according to the procedure described in Frignani et al. (1993).

Thermal analyses were carried out by a Setaram TAG24 double furnace apparatus with simultaneous registration of thermogravimetric (TG), derivative thermogravimetric (TDG) and differential thermal analysis (DTA). The heating rate was fixed at $20{ }^{\circ} \mathrm{C} \mathrm{min}{ }^{-1}$. A $\mathrm{CO}_{2}$ atmosphere was used to increase the temperature of carbonate decomposition. According to the shape of the DTG curve, the total weight loss was divided into 4 ranges: $\mathrm{H}_{2} \mathrm{O}^{-}$from room temperature to about $200{ }^{\circ} \mathrm{C}$, $\mathrm{OM}\left(200-450{ }^{\circ} \mathrm{C}\right)$ loss related to organic matter decomposition and, possibly, sulfide oxidation; $\mathrm{H}_{2} \mathrm{O}^{+}$from 450 to $700{ }^{\circ} \mathrm{C}$ and $\mathrm{CO}_{2}$ linked to calcite at temperatures greater than $700{ }^{\circ} \mathrm{C}$.

Major and trace element analyses were performed by X-ray fluorescence spectrometry (Philips PW1480 spectrometer equipped with a Rh-tube) on pressed powder pellets following the methods described in Franzini et al. (1972, 1975), Leoni \& Saitta (1976), Leoni et al. (1982) for matrix corrections. The estimated precision and accuracy for trace element determinations, based on international reference standards, are better than 5\% except for those elements at $10 \mathrm{ppm}$ or lower (10-15\%). The chemical data of core SP2 are reported in table 2, which also includes the quantitative data from thermal analyses.

Mineralogical analysis of the bulk dry sub-sample was carried out by the X-ray diffraction method (Philips PW1730 manual diffractometer equipped with a $\mathrm{Cu} \mathrm{Rx}-$ tube). The results (Fig. 3) are plotted as semi-quantitative curves, based on the heights of selected peaks of reflection of the main mineral phases (calcite, dolomite, clay minerals, mica, quartz, plagioclases, k-feldspars, pyrite) according to Tucker (1988).

Six samples of core SP2 $(11.5,18.5,29.5,51.5,57.5$ and $63.5 \mathrm{~cm}$ ) were analyzed for pollen content, according to the procedure described in Alvisi (1993) and Guilizzoni et al. (2001). Pollen preservation was very good and the pollen grains were easily countable (J.R.M. Allen, pers. comm.).

Metal fluxes were calculated from ${ }^{210} \mathrm{~Pb}$ accumulation rates according to the formula (Hamilton-Taylor 1979):

$$
\mathrm{F}=\mathrm{R}(1-\phi) \rho C\left[\mu \mathrm{g} \mathrm{cm}^{-2} \mathrm{y}^{-1}\right]
$$

where $\mathrm{R}$ is the sedimentation rate, $\phi$ is the porosity, $\rho$ the dry density and $\mathrm{C}$ the metal concentration.

\section{RESULTS AND DISCUSSION}

\subsection{Lithostratigraphy}

The sediment core SP1 can be subdivided into five lithostratigraphic units numbered from the top to the 


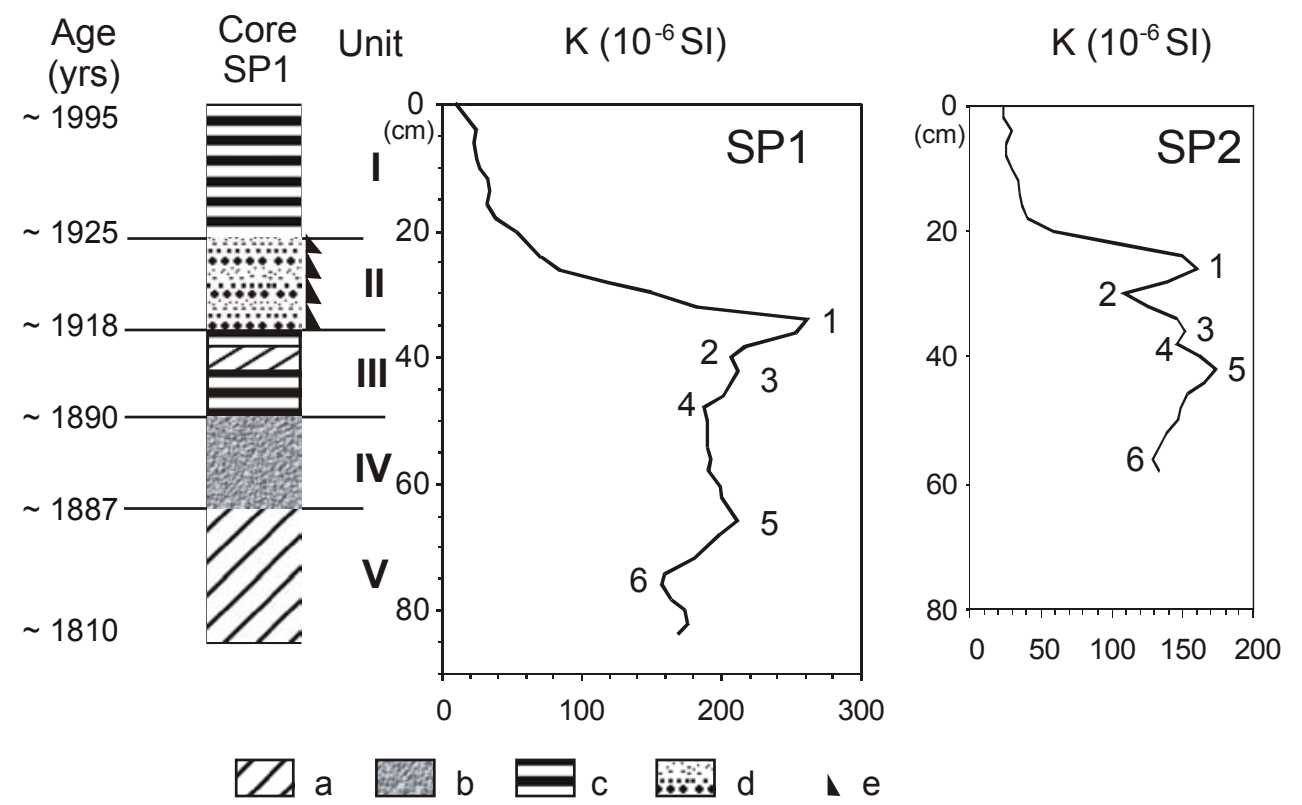

Fig. 2. Lithological description of the core SP1 (a: oblique laminated clay; b: massive clay; c: horizontally laminated clay; d: graded layers from medium sand to clay; e: turbidites) and whole-core volume magnetic susceptibility (K) of the two cores SP1 and SP2. Numbers indicate correlation keys. The chronology is derived from ${ }^{210} \mathrm{~Pb}$ data.

Tab. 1. Lithological description of core SP1.

\begin{tabular}{|c|c|c|}
\hline Unit & Depth $(\mathrm{cm})$ & Description \\
\hline I & $\begin{array}{c}0-9 \\
9-14 \\
14-22\end{array}$ & $\begin{array}{l}\text { well defined whitish and grey carbonatic-rich layers }\left(\mathrm{CaCO}_{3}>0 \%\right) \text { alternated with } \\
\text { black organic-rich clay layers (thickness of the laminae } 1-3 \mathrm{~mm}) ; \\
\text { dark grey organic-rich clay with some faint laminations; } \\
\text { the same as in the first part, but the laminae are not so well defined; }\end{array}$ \\
\hline II & $22-35$ & $\begin{array}{l}\text { series of brown layers graded from medium sand to clay and } 2-3 \mathrm{~cm} \text { thick; the } \\
\text { uppermost one is made only by plant remains; }\end{array}$ \\
\hline III & $\begin{array}{l}35-37 \\
37-41 \\
41-48\end{array}$ & $\begin{array}{l}\text { black organic-rich clay; } \\
\text { dark-brown clay with traces of oblique laminations; } \\
\text { black organic-rich clay intercalated with brown clay; }\end{array}$ \\
\hline IV & $48-65$ & black organic-rich clay with spotted brown clay disturbed by gas bubbles; \\
\hline $\mathrm{V}$ & $65-86$ & $\begin{array}{l}\text { black organic-rich clay intercalated with brown-orange clay with oblique } 2-3 \mathrm{~mm} \\
\text { thick laminations not well defined due to presence of gas bubbles. }\end{array}$ \\
\hline
\end{tabular}

bottom (Tab. 1). The correlation between cores SP1 and $\mathrm{SP} 2$ is illustrated in figure 2 :

(I) 0-22 cm: black organic-rich clay interbedded with spotted brown clay, with an upward increase in alternations of more or less defined laminae of whitish and gray authigenic calcite and diatom/organicrich clay, which were interpreted as varves, well defined only in the topmost $9 \mathrm{~cm}$ of the core, corresponding to $\mathrm{cm} 0-21$ of SP2.

(II) $22-35 \mathrm{~cm}$ : graded muddy to silty sandy layers, sometimes with organic debris at the top, corresponding to $\mathrm{cm} 21-30$ of SP2:

(III) $35-48 \mathrm{~cm}$ : black organic-rich clay interbedded with spotted brown clay similar to (I), corresponding to cm 30-40 of SP2:
(IV) 48-65 cm: black organic-rich clay interbedded with spotted brown clay sometimes disturbed by gas bubbles, corresponding to $\mathrm{cm} 40-44$ of core SP2:

(V) $65-86 \mathrm{~cm}$ : black organic-rich clay intercalated with spotted brown-orange clay sometimes with traces of laminations and gas bubbles, corresponding to $\mathrm{cm} 44-66$ of SP2.

All the transitions from one unit to the next are gradual except within Unit II, where the contacts between the graded layers are abrupt and possibly erosive. The turbiditic intervals (Units II and IV) represent an almost instantaneous depositional signal which is related to shoreline adjustments following major changes in lake hydrology. They represent physical boundaries between well-defined lithological units, deposited under relatively calm conditions. 
Tab. 2. Chemical composition of samples of core SP2. Sample labels indicate the depth downcore. $\mathrm{H}_{2} \mathrm{O}^{-}$, OM (Organic Matter) and $\mathrm{H}_{2} \mathrm{O}^{+}$determination from thermogravimetric analyses (see text for details); n.d. $=$ not detected.

\begin{tabular}{|c|c|c|c|c|c|c|c|c|c|c|c|}
\hline Sample & 2.25 & 3.5 & 6.5 & 9.5 & 13.5 & 17.5 & 21.5 & 23.5 & 27.5 & 31.5 & 34.5 \\
\hline $\mathrm{SiO}_{2}(\mathrm{wt} \%)$ & 21.78 & 29.88 & 16.84 & 19.43 & 29.91 & 25.79 & 36.59 & 55.77 & 54.58 & 36.14 & 28.50 \\
\hline $\mathrm{TiO}_{2}$ & 0.31 & 0.52 & 0.18 & 0.15 & 0.40 & 0.36 & 0.73 & 0.95 & 1.02 & 0.70 & 0.61 \\
\hline $\mathrm{Al}_{2} \mathrm{O}_{3}$ & 6.53 & 10.44 & 3.66 & 3.22 & 8.74 & 7.46 & 14.09 & 20.06 & 20.49 & 14.08 & 11.53 \\
\hline $\mathrm{Fe}_{2} \mathrm{O}_{3}$ & 2.52 & 4.03 & 1.75 & 1.70 & 3.98 & 3.68 & 5.60 & 5.11 & 5.27 & 5.79 & 4.93 \\
\hline $\mathrm{MnO}$ & 0.07 & 0.08 & 0.05 & 0.06 & 0.07 & 0.06 & 0.08 & 0.05 & 0.08 & 0.10 & 0.10 \\
\hline $\mathrm{MgO}$ & 1.27 & 1.34 & 1.13 & 0.97 & 1.24 & 1.28 & 1.29 & 1.37 & 1.30 & 1.78 & 1.75 \\
\hline $\mathrm{CaO}$ & 31.79 & 24.47 & 39.08 & 38.39 & 27.35 & 30.03 & 18.32 & 2.03 & 1.78 & 15.47 & 24.33 \\
\hline $\mathrm{Na}_{2} \mathrm{O}$ & 0.51 & 0.49 & 0.40 & 0.29 & 0.44 & 0.45 & 0.50 & 0.92 & 0.73 & 0.61 & 0.46 \\
\hline $\mathrm{K}_{2} \mathrm{O}$ & 0.57 & 0.79 & 0.36 & 0.27 & 0.70 & 0.66 & 1.06 & 1.88 & 1.73 & 1.21 & 0.96 \\
\hline $\mathrm{P}_{2} \mathrm{O}_{5}$ & 0.09 & 0.10 & 0.06 & 0.03 & 0.08 & 0.06 & 0.08 & 0.16 & 0.14 & 0.13 & 0.12 \\
\hline $\mathrm{H}_{2} \mathrm{O}^{-}$ & 3.23 & 3.34 & 1.57 & 1.80 & 4.17 & 2.63 & 3.77 & 4.28 & 4.76 & 4.03 & 3.40 \\
\hline OM & 3.74 & 3.16 & 3.35 & 2.84 & 2.76 & 2.85 & 2.23 & 1.56 & 2.20 & 3.96 & 4.66 \\
\hline $\mathrm{H}_{2} \mathrm{O}^{+}$ & 4.29 & 4.43 & 2.75 & 2.80 & 4.05 & 3.51 & 4.91 & 4.67 & 4.83 & 5.86 & 5.58 \\
\hline $\mathrm{CO}_{2}$ & 23.27 & 16.92 & 28.81 & 28.06 & 18.11 & 21.19 & 10.76 & 1.20 & 1.08 & 10.14 & 13.07 \\
\hline $\mathrm{S}$ & 1.31 & 1.69 & 1.20 & 1.20 & 1.59 & 1.40 & 1.20 & 0.04 & 0.05 & 1.56 & 1.38 \\
\hline $\mathrm{V}$ (ppm) & 66 & 102 & 42 & 43 & 90 & 79 & 125 & 150 & 156 & 131 & 108 \\
\hline $\mathrm{Cr}$ & 54 & 75 & 33 & 30 & 68 & 56 & 111 & 110 & 113 & 201 & 107 \\
\hline Co & 3 & 4 & nd & nd & 6 & 4 & 12 & 11 & 11 & 18 & 11 \\
\hline $\mathrm{Ni}$ & 28 & 37 & 21 & 21 & 37 & 32 & 46 & 45 & 41 & 45 & 39 \\
\hline $\mathrm{Cu}$ & 41 & 47 & 35 & 37 & 46 & 47 & 39 & 20 & 34 & 22 & 29 \\
\hline $\mathrm{Zn}$ & 67 & 85 & 62 & 41 & 50 & 45 & 65 & 70 & 73 & 62 & 58 \\
\hline $\mathrm{Ga}$ & 7 & 12 & 6 & 8 & 13 & 9 & 15 & 14 & 18 & 17 & 16 \\
\hline $\mathrm{Rb}$ & 79 & 105 & 53 & 53 & 105 & 93 & 144 & 197 & 229 & 114 & 112 \\
\hline $\mathrm{Sr}$ & 331 & 284 & 390 & 378 & 246 & 253 & 200 & 133 & 133 & 164 & 263 \\
\hline $\mathrm{Y}$ & 17 & 26 & 11 & 10 & 23 & 20 & 36 & 46 & 50 & 26 & 22 \\
\hline $\mathrm{Zr}$ & 124 & 199 & 87 & 85 & 172 & 149 & 295 & 397 & 445 & 197 & 196 \\
\hline $\mathrm{Nb}$ & 13 & 17 & 9 & 9 & 17 & 14 & 27 & 34 & 39 & 17 & 17 \\
\hline $\mathrm{Ba}$ & 180 & 287 & 140 & 131 & 240 & 183 & 317 & 462 & 465 & 343 & 324 \\
\hline $\mathrm{La}$ & 33 & 56 & 25 & 14 & 45 & 41 & 62 & 89 & 91 & 61 & 56 \\
\hline $\mathrm{Ce}$ & 67 & 78 & 48 & 34 & 63 & 77 & 101 & 127 & 141 & 131 & 113 \\
\hline $\mathrm{Sc}$ & 31 & 27 & 33 & 38 & 29 & 29 & 26 & 16 & 15 & 28 & 30 \\
\hline $\mathrm{Th}$ & 10 & 18 & 2 & 4 & 20 & 14 & 27 & 28 & 31 & 26 & 19 \\
\hline $\mathrm{Pb}$ & 20 & 30 & 22 & 21 & 29 & 19 & 34 & 46 & 40 & 34 & 31 \\
\hline As & 18 & 20 & 12 & 15 & 19 & 29 & 22 & 14 & 14 & 24 & 19 \\
\hline Mo & 14 & 9 & 9 & 17 & 9 & 10 & 8 & 2 & 2 & 7 & 5 \\
\hline $\mathrm{Se}$ & 4 & 2 & 3 & 3 & 1 & 2 & 2 & 2 & 1 & 3 & 3 \\
\hline $\mathrm{Br}$ & 52 & 47 & 37 & 40 & 27 & 43 & 25 & 19 & 14 & 97 & 157 \\
\hline $\mathrm{U}$ & 3 & 1 & n.d. & 4 & n.d. & 3 & 5 & 8 & 2 & n.d. & 1 \\
\hline
\end{tabular}

(to be continued)

\subsection{Chronology}

Excess ${ }^{210} \mathrm{~Pb}$ was obtained from the radionuclide analysis by subtracting the values of supported ${ }^{210} \mathrm{~Pb}$ from the total. This value is the activity at depth, in the core, where ${ }^{210} \mathrm{~Pb}$ is nearly constant. A value of $79.6 \mathrm{~Bq}$ $\mathrm{kg}^{-1}$ was chosen as a mean background (depth $33-55 \mathrm{~cm}$ of SP2). Figure 4a shows the semi-logarithmic plot of excess ${ }^{210} \mathrm{~Pb}$ as a function of mass depth, to account for the effects of sediment compaction. The excess ${ }^{210} \mathrm{~Pb}$ can be used to calculate average sediment and mass accumulation rates using a CRS (Constant Rate of Supply) model (Appleby \& Oldfield 1978), which gives decreasing rates from the top to $\mathrm{ca} 10 \mathrm{~cm}$ and then quite constant values averaging $0.27 \mathrm{~cm} \mathrm{y}^{-1}$ and $0.11 \mathrm{~g} \mathrm{~cm}^{-2}$ $\mathrm{y}^{-1}$ respectively (Fig. 4b). These values are in good agreement with the sedimentation rates derived from counting the varves of the uppermost portion of core
SP1. In fact, we counted 30 couplets of white-dark laminae in the first $9 \mathrm{~cm}$, which gives a value of 0.30 $\mathrm{cm} \mathrm{y}^{-1}$. The calculated mean rates from both ${ }^{210} \mathrm{~Pb}$ data and varve-counting are somewhat higher than the values obtained for other lakes in Central Italy (e.g. Masaferro et al. 1993; Lami et al. 1994). A depth-variable sedimentation rate for the core is suggested by differences among lithological units. Nevertheless, since we were not able to reconstruct the detailed chronology, we used the mean sedimentation rate, derived both from ${ }^{210} \mathrm{~Pb}$ and varve- counting, as the best tool for core dating. The higher rates could be due to the smaller size and the funnel-like shape of the lake basin, increasing the chance of sediment focusing near the center of the lake floor.

The ${ }^{210} \mathrm{~Pb}$ calculated inventory and mean flux are $187 \mathrm{kBq} \mathrm{m}^{-2}$ and $5800 \mathrm{kBq} \mathrm{m}^{-2} \mathrm{y}^{-1}$ respectively. These values are more than 10 times higher than those of other 
Tab. 2. Continuation.

\begin{tabular}{|c|c|c|c|c|c|c|c|c|c|c|}
\hline Sample & 37.5 & 41.5 & 43.5 & 46.5 & 49.5 & 53.5 & 56.5 & 58.5 & 62.5 & 66.5 \\
\hline $\mathrm{SiO}_{2}(\mathrm{wt} \%)$ & 32.31 & 69.18 & 68.43 & 47.60 & 49.10 & 44.10 & 44.90 & 51.31 & 42.13 & 51.14 \\
\hline $\mathrm{TiO}_{2}$ & 0.67 & 0.36 & 0.37 & 0.86 & 0.88 & 0.83 & 0.87 & 0.84 & 0.85 & 0.88 \\
\hline $\mathrm{Al}_{2} \mathrm{O}_{3}$ & 13.24 & 10.70 & 11.38 & 17.62 & 18.58 & 17.08 & 18.32 & 18.65 & 17.17 & 19.19 \\
\hline $\mathrm{Fe}_{2} \mathrm{O}_{3}$ & 4.85 & 1.90 & 2.11 & 5.42 & 5.64 & 5.88 & 5.77 & 5.32 & 5.72 & 5.92 \\
\hline $\mathrm{MnO}$ & 0.09 & 0.04 & 0.04 & 0.07 & 0.06 & 0.07 & 0.07 & 0.06 & 0.08 & 0.06 \\
\hline $\mathrm{MgO}$ & 1.70 & 0.97 & 0.94 & 1.61 & 1.52 & 1.64 & 1.50 & 1.62 & 1.72 & 1.73 \\
\hline $\mathrm{CaO}$ & 19.09 & 7.36 & 6.47 & 6.96 & 4.32 & 7.27 & 6.30 & 5.70 & 9.50 & 3.41 \\
\hline $\mathrm{Na}_{2} \mathrm{O}$ & 0.64 & 1.33 & 1.13 & 0.70 & 0.65 & 0.64 & 0.58 & 0.77 & 0.57 & 0.77 \\
\hline $\mathrm{K}_{2} \mathrm{O}$ & 1.11 & 2.13 & 2.06 & 1.65 & 1.53 & 1.50 & 1.41 & 1.73 & 1.37 & 1.74 \\
\hline $\mathrm{P}_{2} \mathrm{O}_{5}$ & 0.13 & 0.11 & 0.11 & 0.17 & 0.16 & 0.20 & 0.15 & 0.21 & 0.14 & 0.20 \\
\hline $\mathrm{H}_{2} \mathrm{O}^{-}$ & 3.65 & 1.28 & 0.69 & 4.35 & 5.38 & 5.07 & 5.00 & 3.84 & 4.76 & 5.06 \\
\hline $\mathrm{OM}$ & 4.38 & 1.59 & 1.23 & 3.40 & 3.36 & 3.89 & 3.69 & 2.08 & 3.72 & 3.04 \\
\hline $\mathrm{H}_{2} \mathrm{O}^{+}$ & 5.85 & 1.69 & 1.20 & 6.31 & 6.76 & 8.38 & 8.25 & 5.89 & 6.65 & 5.29 \\
\hline $\mathrm{CO}_{2}$ & 12.30 & 2.40 & 2.82 & 3.28 & 2.08 & 3.49 & 3.21 & 1.97 & 5.62 & 1.57 \\
\hline $\mathrm{S}$ & 1.46 & 0.15 & 0.11 & 0.19 & 0.17 & 1.18 & 0.20 & 0.18 & 0.14 & 0.15 \\
\hline $\mathrm{V}$ (ppm) & 120 & 51 & 55 & 145 & 157 & 150 & 152 & 139 & 143 & 154 \\
\hline $\mathrm{Cr}$ & 145 & 106 & 74 & 116 & 114 & 114 & 113 & 135 & 119 & 139 \\
\hline Co & 13 & nd & nd & 13 & 13 & 13 & 12 & 12 & 14 & 15 \\
\hline $\mathrm{Ni}$ & 38 & 15 & 14 & 39 & 42 & 43 & 39 & 33 & 41 & 36 \\
\hline $\mathrm{Cu}$ & 19 & 7 & 2 & 10 & 5 & 12 & 13 & 10 & 16 & 4 \\
\hline $\mathrm{Zn}$ & 55 & 14 & 15 & 64 & 72 & 71 & 70 & 57 & 59 & 61 \\
\hline $\mathrm{Ga}$ & 12 & 6 & 5 & 12 & 14 & 15 & 15 & 14 & 12 & 16 \\
\hline $\mathrm{Rb}$ & 117 & 90 & 103 & 176 & 183 & 170 & 179 & 150 & 131 & 146 \\
\hline $\mathrm{Sr}$ & 231 & 228 & 245 & 155 & 134 & 140 & 137 & 150 & 132 & 127 \\
\hline Y & 30 & 10 & 12 & 33 & 37 & 34 & 35 & 29 & 31 & 31 \\
\hline $\mathrm{Zr}$ & 245 & 129 & 134 & 299 & 315 & 284 & 322 & 249 & 252 & 261 \\
\hline $\mathrm{Nb}$ & 22 & 7 & 9 & 27 & 28 & 25 & 30 & 22 & 21 & 22 \\
\hline $\mathrm{Ba}$ & 356 & 504 & 481 & 389 & 408 & 371 & 373 & 414 & 382 & 429 \\
\hline $\mathrm{La}$ & 65 & 28 & 27 & 74 & 85 & 82 & 76 & 71 & 76 & 78 \\
\hline $\mathrm{Ce}$ & 115 & 46 & 45 & 113 & 122 & 115 & 120 & 108 & 124 & 118 \\
\hline $\mathrm{Sc}$ & 26 & 10 & 7 & 16 & 16 & 18 & 18 & 18 & 21 & 19 \\
\hline Th & 21 & 7 & 8 & 23 & 25 & 26 & 24 & 22 & 19 & 22 \\
\hline $\mathrm{Pb}$ & 29 & 18 & 21 & 39 & 37 & 43 & 40 & 37 & 39 & 37 \\
\hline As & 19 & 8 & 5 & 12 & 17 & 17 & 19 & 13 & 13 & 14 \\
\hline Mo & 3 & 2 & 4 & 7 & 4 & 6 & nd & nd & 3 & nd \\
\hline $\mathrm{Se}$ & 2 & 2 & 2 & 1 & 1 & 1 & 2 & 1 & 1 & 2 \\
\hline $\mathrm{Br}$ & 135 & 36 & 25 & 74 & 56 & 77 & 61 & 38 & 71 & 25 \\
\hline U & n.d. & n.d. & 4 & 4 & 4 & 5 & 4 & 2 & 2 & 2 \\
\hline
\end{tabular}

Italian lakes (Alvisi \& Frignani 1996; P.G. Appleby, unpubl. data). However, if we consider the inventory values below $10 \mathrm{~cm}$, there is good agreement with those found in literature $\left(11 \mathrm{kBq} \mathrm{m}^{-2}\right)$, and very high values are attained only above $10 \mathrm{~cm}$ depth, i.e. from 1960 to the present. In greater detail, the very marked increase of ${ }^{210} \mathrm{~Pb}$ inventory occurring between $6-10 \mathrm{~cm}$ ( $c a$ between 1960 and 1970) might be attributable to a major discharge of pollutants into the lake basin, leading to eutrophication processes and deep water anoxia; this scenario is suggested by the considerable presence in some layers of sulfur photosynthetic bacteria, as is inferred from their specific carotenoids (A. Lami, pers. comm.).

\subsection{Evolution of sediment composition}

The lithostratigraphic succession outlined above (4.1.) has been used in the following discussion, from the bottom to the top. A Principal Component Analysis (PCA) was performed on the complete data set, excluding those variables with too many missing values.
The F1 vs F2 plots (Fig. 5) explain $82 \%$ of the total variance $(57 \% \mathrm{~F} 1,25 \% \mathrm{~F} 2)$, and the factor loading for each variable in the two eigenvalues is graphically depicted in the inset of figure 5. Negative F1 and positive F2 factor loadings are shown by variables that can be related to the abundance of carbonatic minerals in the sediment (calcite, $\mathrm{CaO}, \mathrm{CO}_{2}, \mathrm{Sr}$ ); $\mathrm{F} 1$ close to 0 and positive $\mathrm{F} 2$ are shown by variables associated to organic matter occurrence (OM, $\mathrm{As}, \mathrm{Br}, \mathrm{MnO})$; highly positive F1 and moderately positive F2 are displayed by elements usually associated to the siliciclastic fraction of the sediment, possibly fine-grained; the last variable association (plagioclases, quartz, k-feldspars, $\mathrm{SiO}_{2}, \mathrm{~K}_{2} \mathrm{O}$, $\mathrm{Na}_{2} \mathrm{O}, \mathrm{Ba}$ ) has positive $\mathrm{F} 1$ and negative $\mathrm{F} 2$ and can be related to a siliciclastic coarse grained fraction occurring in the samples.

Unit $\mathrm{V}$ is characterized by high $\mathrm{F} 1$ and $\mathrm{F} 2$ close to 0 (Fig. 5), which is consistent with a predominance of siliciclastic material, and by a low carbonate content (Fig. 3, and $\mathrm{CaO}$ profile in Fig. 6). On the whole it displays a remarkably constant chemical composition (see 
element profiles and ratios of Fig. 6), except for an isolated peak of $\mathrm{S}$ at $53 \mathrm{~cm}$ depth.

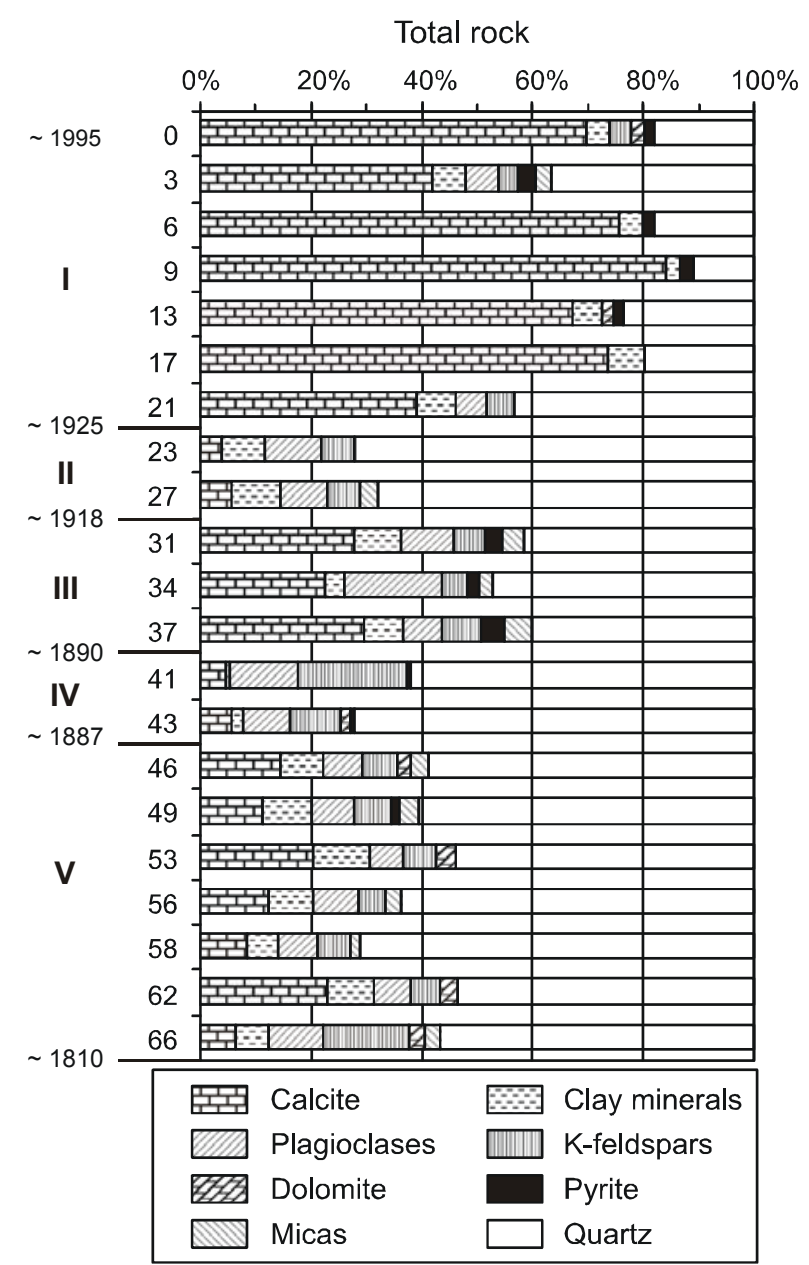

Fig. 3. Semi-quantitative mineralogical composition of SP2 samples, from XRD analyses.

These elements probably derive from material similar to the present dune deposits which are composed of quartz, feldspars, and subordinate limestones and volcanic minerals (Antonioli \& Frezzotti 1989), and thus represent the natural allochthonous fraction of the sediment. The occurrence of sphene in the sediments further supports the presence of a "volcanic" fraction in the sediments. The volcanic minerals probably control the distributions of some important trace elements (e.g. the good correlation between $\mathrm{TiO}_{2}$ and $\mathrm{Cr}, \mathrm{r}=0.73$, Fig. 7a). The low carbonate content of this part of the core suggests that the detrital carbonate contribution to the lake sediments is limited, although there are limestones outcropping on the northern slope of the lake, as well as probably the biogenic one.

The samples of Unit IV are distinct from all the others (Fig. 5), because they show a predominance of coarse-grained siliciclastic minerals, as confirmed by the increase in quartz, k-feldspars and plagioclases, while the carbonate content is still low (Fig. 3). Peaks in $\mathrm{SiO}_{2}$ and $\mathrm{Na}_{2} \mathrm{O}, \mathrm{Si} / \mathrm{Al}$ and $\mathrm{K} / \mathrm{Al}$ confirm this observation (Fig. 6), as do negative peaks recorded in $\mathrm{V}, \mathrm{Cr}, \mathrm{Zn}$, $\mathrm{Ti} / \mathrm{Al}$, which are associated to a fine-grained siliciclastic fraction (Fig. 6). Unit IV can be interpreted as a series of turbidite layers dividing the sedimentary record into two quite distinct parts: the lower one, Unit V, characterized by natural detrital sedimentation and the upper one (Units III, II and I) characterized by increased productivity and authigenic sedimentation (Units III and I). Turbidites of Unit IV could be related to human disturbance on the lake shore, such as the digging of the canal connecting Lake San Puoto to Lake Lungo, which was probably responsible for the mobilization of coarsegrained sediment and for a possible alteration of limnological conditions within the lake, leading to changes in water and sediment chemistry.
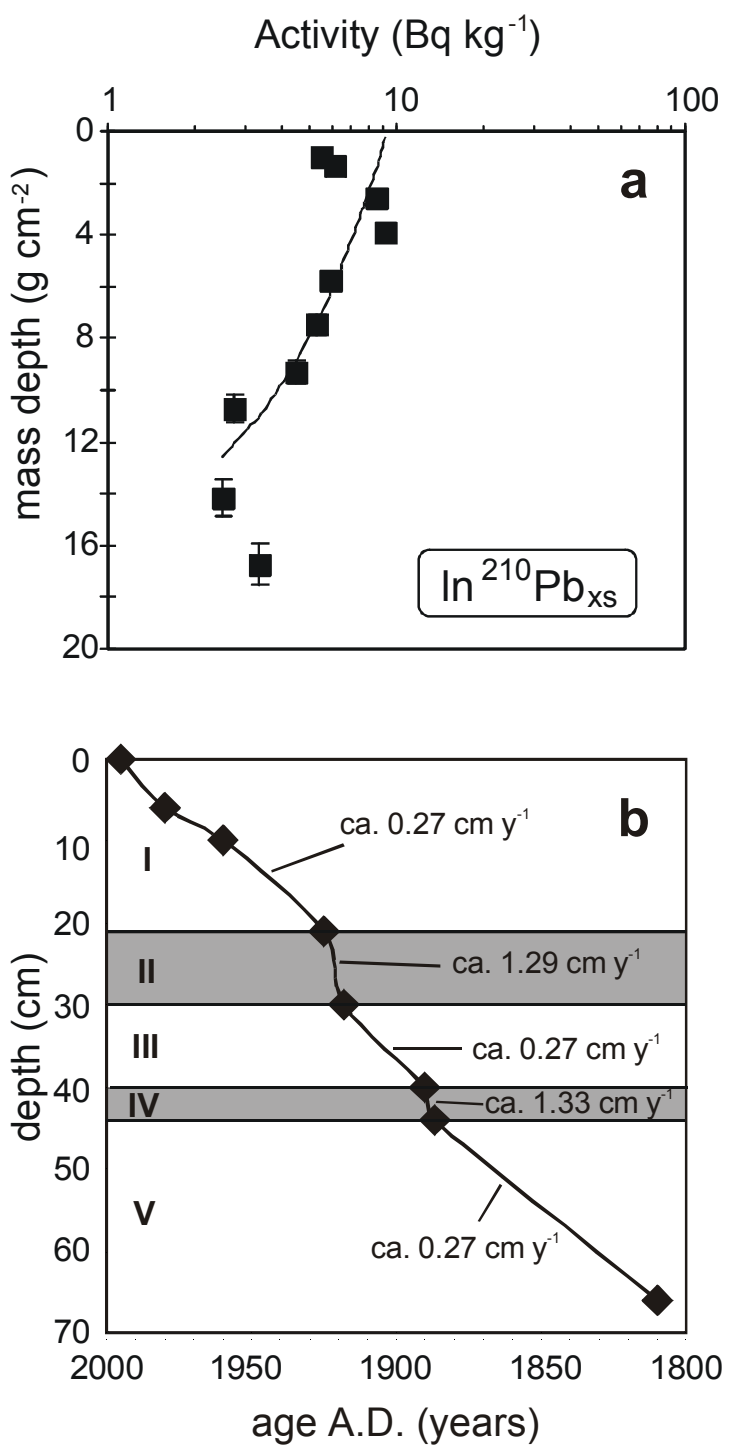

Fig. 4. a) Semi-logarithmic plot of excess ${ }^{210} \mathrm{~Pb}$ and $\mathbf{b}$ ) agedepth profile for core SP2. Shaded layers represent turbiditic events. 


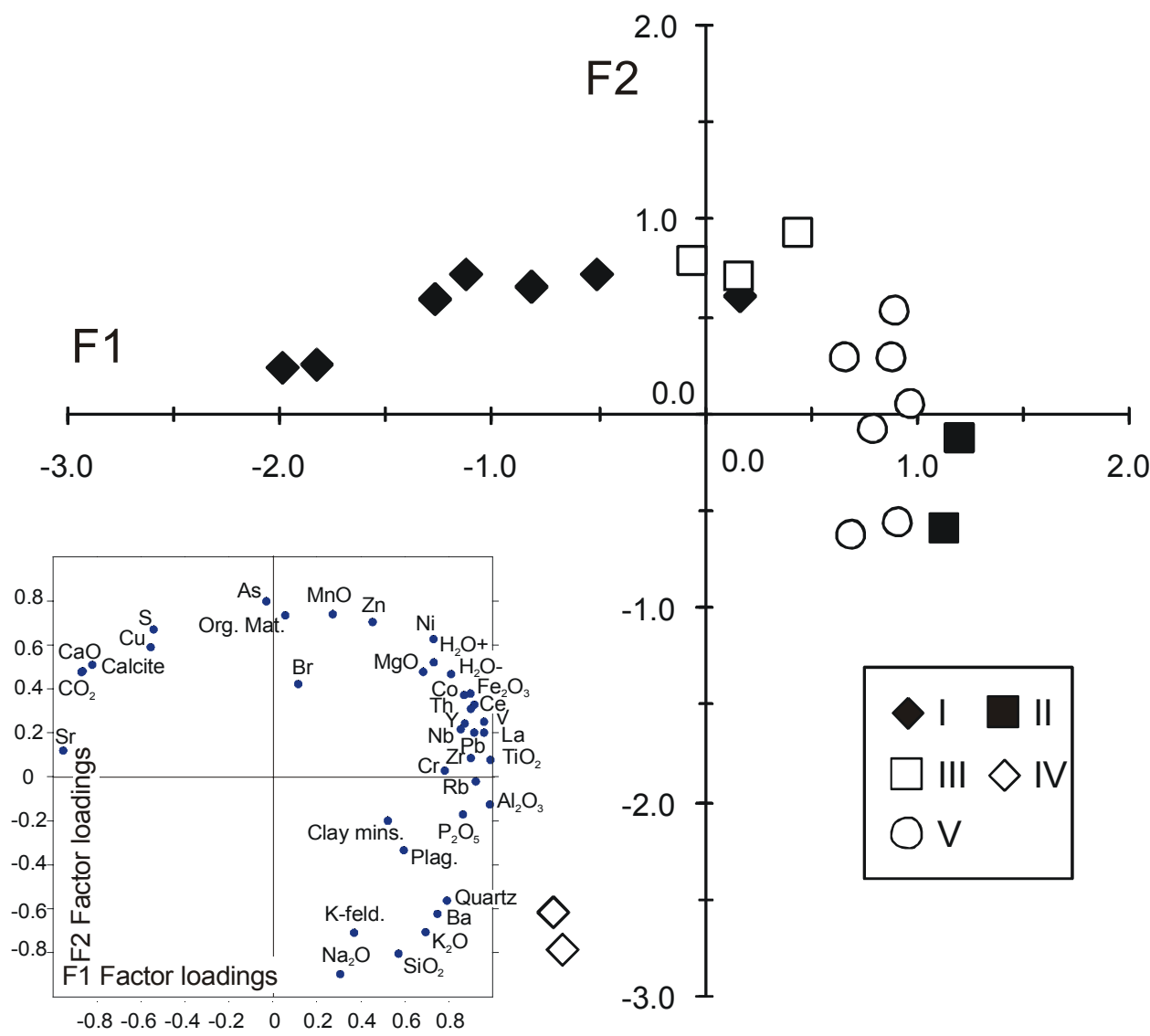

Fig. 5. F1 vs F2 plot from the Principal Component Analysis (symbols refer to the lithostratigraphic units recognized in core SP2). The inset shows the Factor loadings of the variables used in the PCA.

Unit III samples fall in a F1/F2 position (Fig. 5), which suggests an abundance of organic matter, and the vertical profiles show a marked increase in the calcium carbonate content (Fig. 3), mainly at the expense of quartz. In addition, in this unit dolomite disappears and pyrite and plagioclases decrease. The chemical composition is rather complex as a result of the mixing of detrital (siliciclastic and heavy minerals), carbonatic and biogenic fractions. Further evidence of the preservation of organic matter, favored by reducing conditions, comes from the high concentrations of elements, such as $\mathrm{S}, \mathrm{V}, \mathrm{As}$, which are usually enriched in more organic sediments (Fig. 6). Br is also enriched in these layers and displays a good correlation with organic matter (Fig. 7b, $r=0.81$ ), even though some samples with low organic matter plot far from the general trend. This feature has been observed in other lakes in Central Italy, such as Lake Monticchio (Robinson et al. 1993; Robinson 1994) and Lake Albano (Lucchini et al. 1996; Calanchi et al. 1996). Bromine is known to have a strong affinity for land plant material (Cosgrove 1970) and humic substances (Vinogradov 1959), so that its increased accumulation in lake sediments should reflect a period favorable to land plant growth, with consequently larger amounts of organic debris carried into the lake. The origin of bromine is related to ocean-derived aerosols. In fact, samples of Lake San Puoto have a much higher $\mathrm{Br}$ /Organic Matter ratio compared to Lake Albano, which is located $20 \mathrm{~km}$ inland from the Tyrrhenian Sea.

The graded layers of Unit II have the highest F1 values, which suggests an abundance of silicates, perhaps with a tendency to concentrate some coarse-grained phases: quartz, feldspars, plagioclases and clay minerals are abundant and carbonates show a marked decrease (Fig. 3). The vertical profiles of $\mathrm{SiO}_{2}, \mathrm{Al}_{2} \mathrm{O}_{3}, \mathrm{Na}_{2} \mathrm{O}$, V, $\mathrm{Zr}$, (Fig. 6) testify to an increase in detrital input characterized by coarse-grained minerals such as plagioclases (the $\mathrm{Sr} / \mathrm{Ca}$ profile in Fig. 6) and feldspars, but also pyroxenes and sphene. There are plant remains at the top of each layer, one of which seems to consist exclusively of woody fragments and leaves. The accumulation of such a thick layer of plant detritus close to the center of the lake suggests a focusing of sediment input, probably due to a reduction of the lake surface area by a lowering of its level. The graded layers are interpreted as turbidite deposits. In fact, the turbidites are products of the re-deposition from sediment-laden density currents and can usually be recognized, in a sedimentary sequence, by fining-upward grain size, high content of allochthonous detrital matter and sometimes different colors (Lami et al. 1994). According to mineralogical 

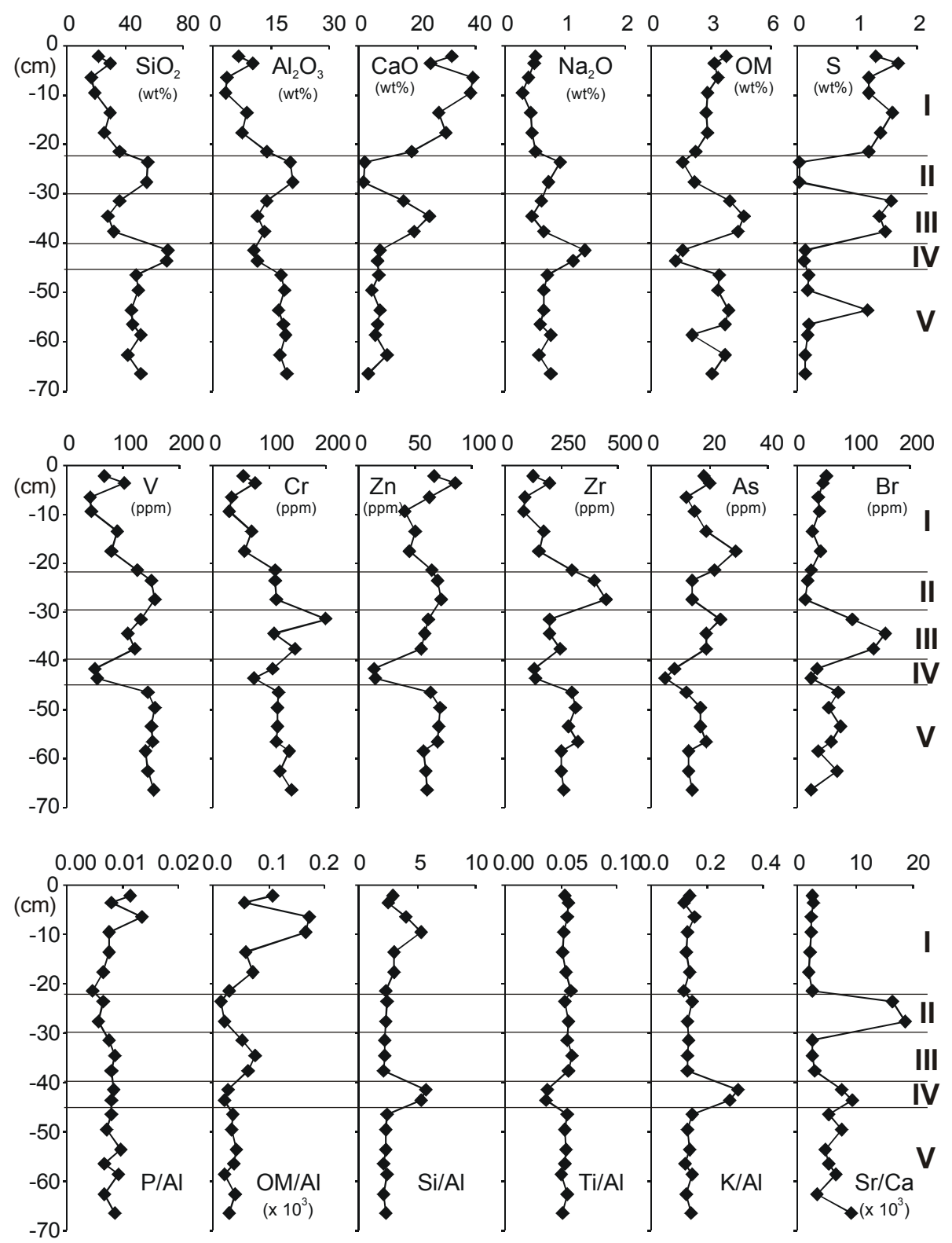

Fig. 6. Downcore variations of selected elements and ratios in core SP2. Lithological units are reported for comparison.

and geochemical features, this unit reflects a local source of sediment with a composition very similar to those of the Holocene and Upper Pleistocene eolian deposits surrounding the lake basin. For all these reasons, the deposition of this unit appears once again to reflect slope instability caused by human disturbances on the lake shore. The building of a recreational area on the lake shore, which certainly required the water level to be lowered, is the likely cause of the presence of coarser sediments near the center of the lake. So far we have no precise historical information regarding land management, but the period in question should be around 1925 AD.

The laminated Unit I, most similar to Unit III, forms the top of the core (from $20 \mathrm{~cm}$ upwards in core SP2).
The laminae represent a cyclical alternation of carbonate-rich layers $\left(\mathrm{CaCO}_{3}\right.$ concentration around $\left.80 \%\right)$ with dark-grey to black silty- and/or organic-rich clay layers. Small amounts of quartz, clay minerals and pyrite occur in the non-carbonaceous layers. The high $\mathrm{Si} / \mathrm{Al}$ ratio compared to other purely detritic indicators ( $\mathrm{Ti} / \mathrm{Al}$, $\mathrm{K} / \mathrm{Al}, \mathrm{Sr} / \mathrm{Ca}$ in Fig. 6), which remain constant, suggests a biogenic origin of silica, perhaps relating to diatom blooms, rather than variations in sediment texture or mineralogical changes. Moreover, the increase of $\mathrm{CaO}$, $\mathrm{P} / \mathrm{Al}$ and $\mathrm{OM} / \mathrm{Al}$ (Fig. 6) further suggests that the deposition of this unit occurred in a very productive basin, with diatom blooms and precipitation of biogenic calcium carbonate. The different laminations reflect seasonal changes in sediment composition, following 
mechanisms described for many eutrophic and meromictic lakes with bottom water anoxia (e.g. Kelts \& Hsü 1978; Züllig 1982; Niessen \& Kelts 1989).
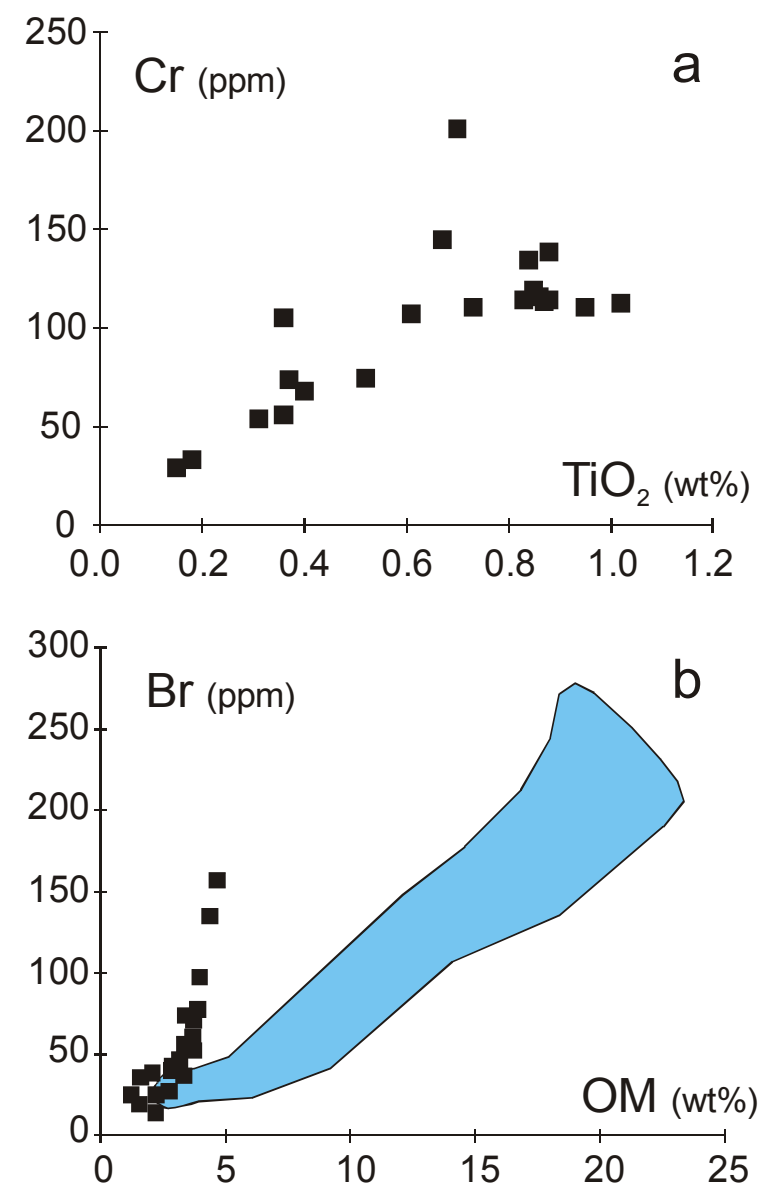

Fig. 7. a) $\mathrm{TiO}_{2}$ vs $\mathrm{Cr}$ relationship in core $\mathrm{SP} 2(\mathrm{r}=0.73)$; b) $\mathrm{OM} v s \mathrm{Br}$ scatter-plot $(\mathrm{r}=0.81)$ (the shaded area represents data from Lake Albano, from Calanchi et al. 1996).

\subsection{Anthropogenic effects}

The reconstructed ${ }^{210} \mathrm{~Pb}$ chronology indicates that eutrophication, well recorded in Unit I (1925-1995), had already begun around the end of the XIX century (Unit III), but increased markedly during the last century, as can be deduced from the growing presence and thickness of the laminations, and from the depth-profiles of geochemical indicators of productivity (Fig. 6). Initially, the nutrient supply was probably related to agricultural practices that modified the vegetational landscape of the Fondi Plain, reducing the extent of the natural maquis vegetation. The pollen assemblage, in fact, indicates that the top three samples are very similar in their pollen assemblages, with around $50 \%$ trees, shrubs and vines, and a percentage of grasses higher than in the older sediments (J.R.M. Allen, pers. comm.). In recent times, on the other hand, the eutrophication of the lake is probably related to an increase of population in this area and to the development of intensive recreational and agricultural activities (e.g. greenhouses).
We can also observe an increase in the heavy metal input to the lake, highlighted by changes in the Al-normalized metal depth profiles (Fig. 8). A significant increase above background levels is recorded, from $20 \mathrm{~cm}$ (about $1930 \mathrm{AD}$ ) upwards, for $\mathrm{Pb}, \mathrm{Ni}, \mathrm{Cu}, \mathrm{Zn}$ and $\mathrm{Cr}$, which reach levels at least twice the background. Only $\mathrm{Cr}$ does not reach the highest normalized values in the uppermost portion of the core, but rather in coincidence with Unit III. This anomaly is probably related to the deposition of volcanic-derived sands enriched in pyroxenes and titanite, which are very common in the coastline sands of the area (Brondi et al. 1979).

The metal fluxes of $\mathrm{Zn}, \mathrm{Cu}$ and $\mathrm{Pb}$ are higher (Tab. 3 ) in the upper portion of the core (above $10 \mathrm{~cm}$, about 1960 AD) than in the remaining part of the core, similarly to the Al-normalized trends. Higher values of the fluxes are observed in deeper sections, but this might be partially influenced by diagenetic remobilization and sediment grain size. The calculated metal fluxes, however, are not so high when compared to those observed in other lakes (see summary table in Salomons \& Förstner 1984) that record a more significant anthropogenic input (e.g. lakes Erie and Ontario). They might instead be more comparable with data reported by Lottermoser et al. (1997) for Lake Holzmaar in Germany, which is relatively far from significant sources of pollution. The sharp increase of metal fluxes in the very recent sediments (after 1960) could be related to the use of chemicals in the specialized agricultural activities which developed around the lake and, more in general, to the growth of human activities both around and within the lake.

Independent evidence of a similar environmental evolution is provided by the pollen assemblage, indicating a well-diversified flora in the lower portion of the core (a total of 66 land pollen types plus 5 aquatic species and several types of spores), which evolves in the surface sample to show high percentages of mainly Pinus and Cyperaceae and less diversity of the herbaceous taxa (J.R.M. Allen, pers. comm.). This could be interpreted as the result of the intensive human use of the surrounding area for recreational activities. Presently, the lake is intensively exploited for water skiing and the recreational activities mentioned above. There is also the fact that the area between the lake and the sea shore is covered by pine woods with many camping sites.

\section{CONCLUSIONS}

The evolution of the recent sedimentation (last 200 years) of the coastal Lake San Puoto is characterized by the interplay of three main components: detrital (siliciclastic and/or carbonatic), organic-rich and authigenic phases. The first reflects the input from coastal dunes and rocky outcrops, while the others indicate variations in lake productivity. The organic fraction should reflect both origins, allochthonous and autochthonous, de- 


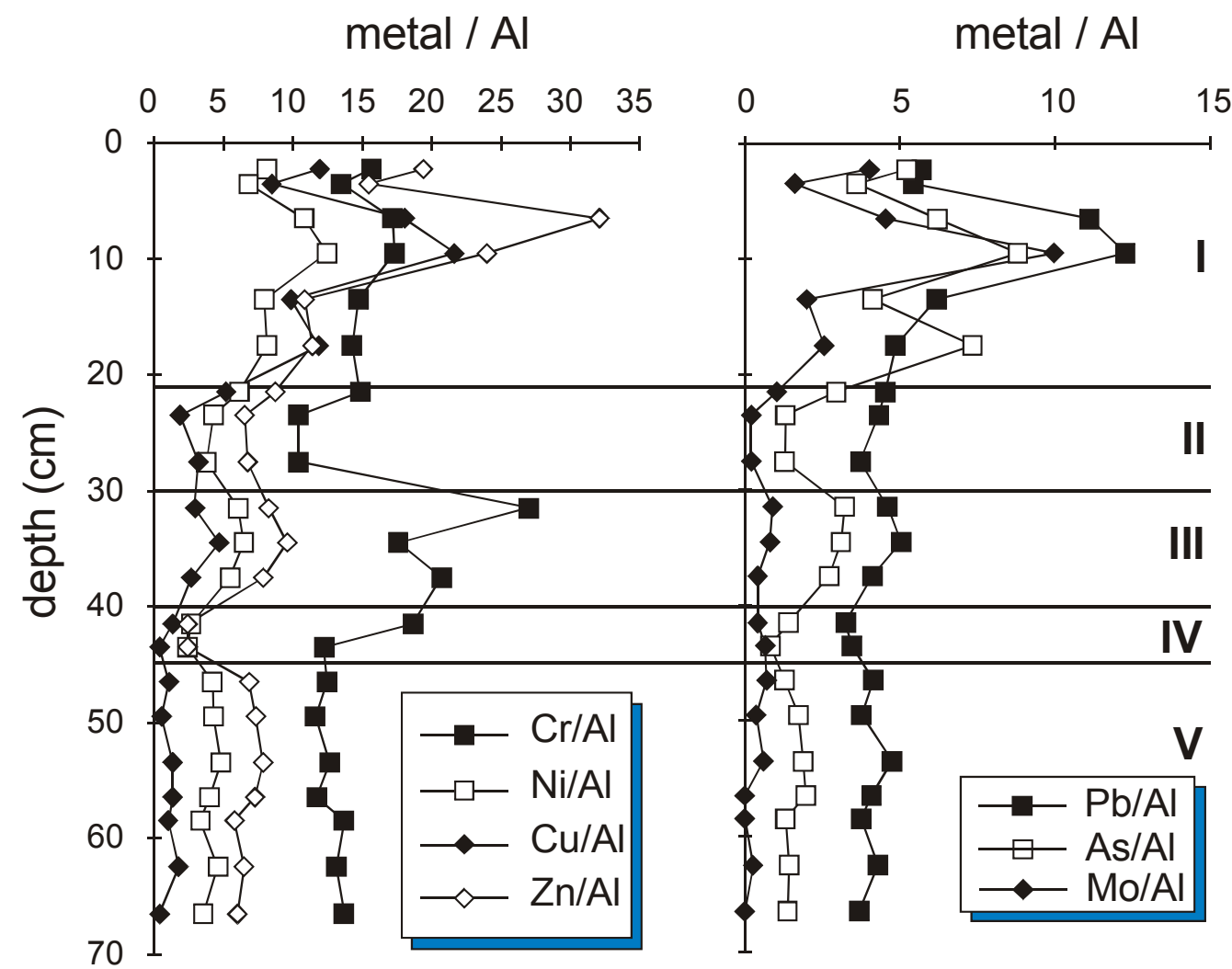

Fig. 8. Downcore pattern of A1/normalized metals in core SP2.

Tab. 3. Calculated apparent accumulation rates of $\mathrm{Pb}, \mathrm{Cu}, \mathrm{Zn} \mathrm{Cr}$ and $\mathrm{As}$ for core $\mathrm{SP} 2$ (see text for details).

\begin{tabular}{lcccccc}
\hline $\begin{array}{l}\text { depth } \\
\mathrm{cm}\end{array}$ & year & $\begin{array}{c}\mathrm{Pb} \\
\left(\mu \mathrm{g} \mathrm{cm}^{-2} \mathrm{y}^{-1}\right)\end{array}$ & $\begin{array}{c}\mathrm{Cu} \\
\left(\mu \mathrm{g} \mathrm{cm}^{-2} \mathrm{y}^{-1}\right)\end{array}$ & $\begin{array}{c}\mathrm{Zn} \\
\left(\mu \mathrm{g} \mathrm{cm}^{-2} \mathrm{y}^{-1}\right)\end{array}$ & $\begin{array}{c}\mathrm{Cr} \\
\left(\mu \mathrm{gm}^{-2} \mathrm{y}^{-1}\right)\end{array}$ & $\begin{array}{c}\mathrm{As} \\
\left(\mu \mathrm{gm}^{-2} \mathrm{y}^{-1}\right)\end{array}$ \\
\hline 2.25 & 1995 & 1.6 & 3.2 & 5.2 & 4.2 & 1.4 \\
3.5 & 1995 & 2.9 & 4.6 & 8.4 & 7.4 & 2.0 \\
6.5 & 1990 & 2.3 & 3.7 & 6.5 & 3.5 & 1.3 \\
9.5 & 1962 & 2.5 & 4.5 & 4.9 & 3.6 & 1.8 \\
13.5 & 1903 & 3.2 & 5.1 & 5.5 & 7.5 & 2.1 \\
17.5 & 1875 & 2.1 & 5.2 & 5.0 & 6.2 & 3.2 \\
21.5 & 1846 & 3.7 & 4.3 & 7.2 & 12.2 & 2.4 \\
\hline
\end{tabular}

pending on the hydrological regime and land management. The semi-circular and funnel-like shape and the small size of the lake mean that it can respond very quickly to environmental changes. Nevertheless, the presence of turbiditic layers and oblique lamination suggest slope instability, and thus the need for a better understanding of the lake floor morphology, before a longer coring study is planned.

The area does not seem to pose serious environmental problems, since industrial pollution, as revealed by increased metal fluxes, has been in evidence only in the last thirty years and has not reached severe levels. However, increased eutrophication, together with changes in the physical and chemical conditions of the lake environment, as suggested by the sedimentary record (presence of laminated sediments), and by the recent red algal blooming observed seasonally on the lake surface, point to a progressive deterioration of the lake water quality. Since the lake is used for recreational and agricultural purposes, a better understanding of the effect of these changes on water chemistry and sedimentary input is needed.

The present study has highlighted various disturbances occurring in Lake San Puoto over the last two centuries, including: the establishment of settlements along the shoreline, leading to sediment resuspension and basin erosion dating back to 1890 , and increased metal fluxes and signs of eutrophication since 1960. Nevertheless, the absence of widespread pollution problems during the recent past (before 1960 AD) should be a positive aspect in further studies devoted to the biology of the lake. Lake San Puoto might actually have had a relatively pristine situation prior to $1900 \mathrm{AD}$, thus enabling palaeobiological reconstruction. Further- 
more, this lake could be a key site for studying Late Pleistocene-Holocene sea level variations and climatic changes along the Tyrrhenian coastline, thanks to its unique low altitude location and its possible episodic connections to the sea. The full time span covered by the sedimentary record of the lake is unknown, but will certainly include most, if not all, of the late Holocene (last $c a$ 3-4 ky). It is to be hoped that a future study on this lacustrine sedimentary record will add information on the Late Pleistocene/Holocene palaeoclimatic evolution of Central-Southern Italy.

\section{ACKNOWLEDGMENTS}

This study was carried out in the framework of the EU ENVIRONMENT-funded project PALICLAS (EU5V-CT93-0267) investigating the Last Glacial-Interglacial transition. We thank F. Oldfield for his encouragement, for stimulating discussion and for his critical reading of the paper, A. Cessari and F. Oldfield for their extraordinary help during the core collection and all the field work, J.R.M. Allen for pollen counting and interpretation, V. Landuzzi for X-ray diffraction analysis, E. Lipparini for ${ }^{210}$ Po extractions and G. Marozzi for photographs and radiographs of core SP1. The comments of P. Guilizzoni and an anonymous referee were much appreciated. This is a contribution $\mathrm{n}^{\circ} 1273$ of the Istituto per la Geologia Marina, CNR, Bologna.

\section{REFERENCES}

Alvisi, F. 1993. Ricostruzione paleoambientale dei laghi sudalpini Orta, Varese, Mergozzo e Ganna attraverso un'analisi dei sedimenti olocenici e attuali. Ph.D. unpublished thesis, Univ. of Bologna, Italy.

Alvisi, F. \& M. Frignani. 1996. ${ }^{210} \mathrm{~Pb}$-derived sediment accumulation rates for the central Adriatic Sea and crater lakes Albano and Nemi (central Italy). Mem. Ist. ital. Idrobiol., 55: 303-320.

Antonioli, F. \& M. Frezzotti. 1989. I sedimenti tardo-pleistocenici ed olocenici compresi nella fascia costiera tra Sabaudia e Sperlonga. Mem. Soc. Geol. It., 42: 321-334.

Antonioli, F., M. Frezzotti \& E. Valpreda. 1989. Evoluzione geologica della piana di Fondi e delle aree marginali durante il Quaternario. Mem. Descr. Carta Geol. d'It., XXXVIII.

Appleby, P.G. \& F. Oldfield. 1978. The calculation of lead210 dates assuming a constant rate of supply of unsupported ${ }^{210} \mathrm{~Pb}$ to the sediment. Catena, 5: 1-8.

Battarbee, R.W., J. Mason, I. Renberg \& J.F. Talling (Eds). 1990. Palaeolimnology and lake acidification. Philosophical Transactions of the Royal Society of London, Series B: Biological Sciences. 327(1240): 227-445.

Baudo, R. \& M. Beltrami. 2001. Chemical composition of Lake Orta sediments. J. Limnol., 60(2): 213-236.

Brondi, A., O. Ferretti, B. Anselmi \& G. Falchi. 1979. Analisi granulometriche e mineralogiche dei sedimenti fluviali e costieri del territorio italiano. Boll. Soc. Geol. It., 98: 239326.

Busatti, G., A. Magagnoli \& M. Mengoli. 1980. Un nuovo carotiere a gravitá acqua-sedimento. Rapp. Tecn. n. 12, I.G.M.-C.N.R., Bologna.

Calanchi, N., E. Dinelli, F. Lucchini \& A. Mordenti. 1996. Chemostratigraphy of Late Quaternary sediments from Lago di Albano and Central Adriatic sea cores
(PALICLAS Project). Mem. Ist. ital. Idrobiol., 55: 247263.

Cosgrove, M.E. 1970. Iodine in the bitominous Kimmeridge Shales of the Dorset Coast. Geochim. Cosmochim. Acta, 34: 830-836.

Creer, K.M. \& A. Morris. 1996. Proxy-climate and geomagnetic palaeointensity records extending back to $c a 75,000$ BP derived from sediments cored from Lago Grande di Monticchio, Southern Italy. Quat. Sci. Rev., 15: 167-188.

Das, B.K., M. Singh \& R. Van Grieken. 1995. The elemental chemistry of sediment in the Nainital Lake, Kumaun Himalaya, India. Sci. Total Environ., 168: 85-90.

Duck, R.W., J.A. Dearing, B. Zolitschka, I. Renberg, B. Frenzel, J.F.W. Negendank, J. Merkt, C. Giraudi \& S.O. Dahl. 1998. Physical records from lakes; the discrimination between signals due to changes in lake water depth and those due to changes in catchment processes. In: Harrison S.P., B. Frenzel, U. Huckriede, M.M. Weib (Eds), Paleohydrology as reflected in lake-level changes as climatic evidence for Holocene times. Paleoclimate Research, 25: 149-160.

Förstner, U. \& G.T.W. Wittmann. 1979. Metal pollution in the aquatic environment. Springer-Verlag, Berlin: $486 \mathrm{pp}$.

Franzini, M., L. Leoni \& M. Saitta. 1972. A simple method to evaluate the matrix effects in X-Ray fluorescence analysis. $X$-Ray Spectrom., 1: 151-154.

Franzini, M., L. Leoni \& M. Saitta. 1975. Revisione di una metodologia analitica per fluorescenza-X, basata sulla correzione completa degli effetti di matrice. Rend. Soc. It. Min. Petrol., 31: 365-378.

Frignani, M., L. Langone, S. Albertazzi \& M. Ravaioli. 1993. Cronologia di sedimenti marini- Analisi di ${ }^{210} \mathrm{~Pb}$ via ${ }^{210} \mathrm{Po}$ per spettrometria alfa. Techn. Rep. n. 28, I.G.M.-C.N.R., Bologna.

Guilizzoni, P., A. Lami, A. Marchetto, P.G. Appleby \& F. Alvisi. 2001. Fourteen years of palaeolimnological research of a past industrial polluted lake (L. Orta, Northern Italy): an overview. J. Limnol., 60(2): 249-262.

Håkanson, L. \& M. Jansson. 1983. Principles of lake sedimentology. Springer-Verlag, Berlin: $316 \mathrm{pp}$.

Hamilton-Taylor, J. 1979. Enrichments of $\mathrm{Zn}, \mathrm{Pb}$ and $\mathrm{Cd}$ in recent sediments of Windermere, England. Environ. Sci. Technol., 13: 393-397.

Kelts, K. \& K.J. Hsu. 1978. Freshwater carbonate sedimentation. In: A. Lerman (Ed.), Lakes: Chemistry, Geology, Physics. Springer-Verlag, New York: 295-323.

Lami, A., F. Niessen, P. Guilizzoni, J. Masaferro \& C.A. Belis. 1994. Paleolimnological studies of the eutrophication of volcanic Lake Albano (Central Italy). J. Paleolimnol., 10: 181-197.

Leoni, L. \& M. Saitta. 1976. X-ray fluorescence analysis of 29 trace elements in rock and mineral standard. Rend. Soc. It. Min. Petrol., 32: 497-510.

Leoni, L., M. Menichini \& M. Saitta. 1982. Determination of $\mathrm{S}, \mathrm{Cl}$, and $\mathrm{F}$ in silicate rocks by X-Ray fluorescence analyses. X-Ray Spectrom., 11: 156-158.

Lottermoser B.G., U. Schütz, J. Boenecke, R. Oberhänsli, B. Zolitschka \& J.F.W. Negendank. 1997. Natural and anthropogenic influences on the geochemistry of Quaternary lake sediments from Holzmaar, Germany. Env. Geol., 31(3/4): 236-247.

Lucchini, F., N. Calanchi \& E. Dinelli. 1996. Sediment geochemistry of Lago di Albano (Central Italy): records of palaeoenvironmental changes in Late Quaternary. Plinius, 16: 134-136.

Masaferro, J., A. Lami, P. Guilizzoni \& F. Niessen. 1993. Record of changes in the fossil chironomids and other parameters in the volcanic Lake Nemi (Central Italy). Verh. int. Ver. Limnol., 25: 1113-1116.

Niessen, F. \& K. Kelts. 1989. The deglaciation and Holocene sedimentary evolution of southern perialpine Lake Lugano 
- implications for Alpine paleoclimate. Eclogae geol. Helv., 82(1): 235-263.

Oldfield, F. 1991. Environmental magnetism - a personal perspective. Quat. Sci. Rev., 10: 73-85.

Oldfield, F. \& M. Frignani. 1996. The magnetic properties of nine short cores from the North West Adriatic: a preliminary report. Proceeding of Workshop 4, Progetto strategico clima, ambiente e territorio nel Mezzogiorno, Lecce, 1991: 217-242.

Pagnotta, R., T. La Noce, M. Pettine \& A. Puddu. 1986. I laghi dell'Italia centrale: classificazione trofica ed analisi dei fattori che la influenzano. Atti $7^{\circ}$ Congresso A.I.O.L., Trieste 11-14 Giugno 1986: 385-396.

Petterson, G., I. Renberg, P. Geladi, A. Lindberg \& F. Lindgren. 1993. Spatial uniformity of sediment accumulation in varved lake sediments in northern Sweden. $\mathrm{J}$. $\mathrm{Pa}$ leolimnol., 9(3): 195-208.

Premazzi, G., A. Provini, G.F. Gaggino \& G. Parise. 1986 Geochemical trends in sediments from 13 italian subalpine lakes. In: P.G. Sly (Ed.), Sediments and water interaction. Springer-Verlag, Berlin: 157-165.

Renberg, I., T. Korsman \& H.J.B. Birks. 1993. Prehistoric increases in the $\mathrm{pH}$ of acid-sensitive Swedish lakes caused by land-use changes. Nature (London), 362 (6423): 824827.

Renberg, I., M.W. Persson \& O. Emteryd. 1994. Pre-industrial atmospheric lead contamination detected in Swedish lake sediments. Nature (London), 368(6469): 323-326.
Robinson, C. 1994. Lago Grande di Monticchio, southern Italy: a long record of environmental change illustrated by sediment geochemistry. Chem. Geol., 118: 235-254.

Robinson, C., G.B. Shimmield \& K.M. Creer. 1993. Geochemistry of Lago Grande di Monticchio, S. Italy. In J.F.W. Negendank \& B. Zolitschka (Eds), Paleolimnology of European Maar Lakes. Springer-Verlag, Berlin, Lecture Notes in Earth Sciences, 49: 317-332.

Rolph, T.C., F. Oldfield \& K. Van der Post. 1996. Palaoemagnetism and rock-magnetism results from Lake Albano and the Central Adriatic Sea (Italy). Mem. Ist. ital. Idrobiol., 55: 265-283.

Rosen, P., R. Hall, T. Korsman \& I. Renberg. 2000. Diatom transfer-functions for quantifying past air temperature, $\mathrm{pH}$ and total organic carbon concentration from lakes in northern Sweden. J. Paleolimnol., 24(2): 109-123.

Salomons, W. \& U. Förstner. 1984. Metals in the hydrocycle. Springer-Verlag, Berlin: 349 pp.

Tucker, M.E. (Ed.). 1988. Techniques in sedimentology. Blackwell Scientific Publication, Oxford: 394 pp.

Verosub, K.L. \& A.P. Roberts. 1995. Environmental magnetism: past, present, and future. J. Geoph. Res., 100: 21752192.

Vinogradov, A.P. 1959. The geochemistry of rare and dispersed chemical elements in soils. $2^{\text {nd }}$ edition. Consultant Bureau, New York.

Züllig, H. 1982. Untersuchungen über die Stratigraphie von Carotinoiden im geschichteten Sediment von 10 Schweizer Seen zur Erkundung früherer PhytoplanktonEntfaltungen. Schweiz. Z. Hydrobiol., 44(1): 1-98. 